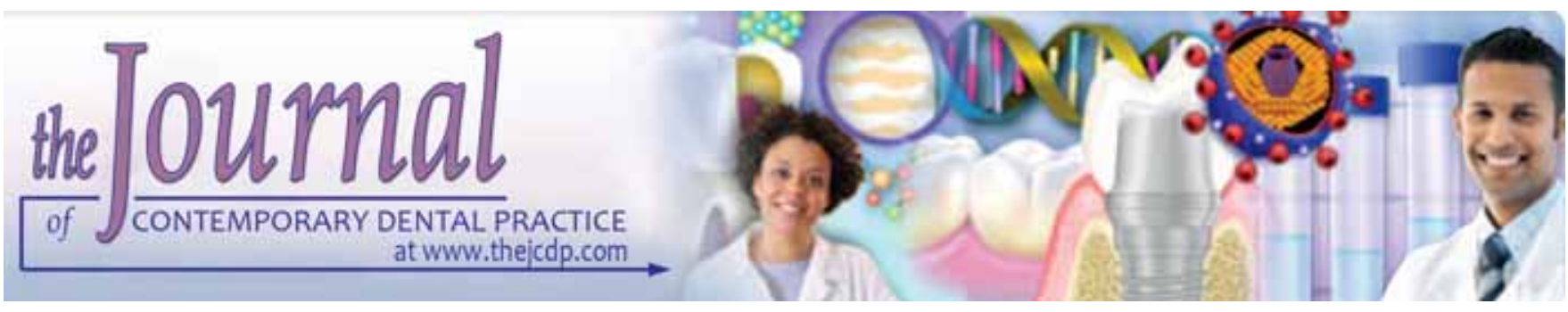

\title{
Effects of Different Cavity Disinfectants on Shear Bond Strength of a Silorane-based Resin Composite
}

\author{
Soley Arslan, A Ruya Yazici, Jale Gorucu, Atilla Ertan, Kanşad Pala, Yakup Üstün \\ Sibel A Antonson, Donald E Antonson
}

\begin{abstract}
Aim: This in vitro study evaluated the effect of different cavity disinfection agents on bond strength of a silorane-based resin composite.
\end{abstract}

Materials and methods: Thirty-six caries-free human third mandibular molars sectioned in mesio-distal direction were mounted in acrylic resin with their flat dentin surfaces exposed. After the dentin surfaces were wet ground with \# 600 silicon carbide paper, the teeth were randomly divided into 6 groups of 12 each according to the cavity disinfection agents; chlorhexidine $(\mathrm{CHX})$; sodium hypochlorite $(\mathrm{NaOCl})$, propolis, ozone, Er,Cr:YSGG laser and no treatment (control). After treatment of dentin surfaces with one of these cavity disinfection agents, Filtek Silorane adhesive system was applied. The silorane-based resin composite, Filtek Silorane was condensed into a mold and polymerized. After storage at $37^{\circ} \mathrm{C}$ for 24 hours, the specimens were tested in shear mode at a crosshead speed of $1.0 \mathrm{~mm} /$ minute. The results were analyzed by one-way ANOVA.

Results: No statistically significant difference was observed between the groups ( $p>0.05$ ).

Conclusion: The use of the tested cavity disinfection agents, chlorhexidine, sodium hypochlorite, propolis, ozone and Er,Cr:YSGG laser did not significantly affect the dentin bond strength of a silorane-based resin composite, Filtek Silorane.

Clinical significance: Cavity disinfectant applications did not affect the dentin bond strength of a silorane-based resin composite.

Keywords: Cavity disinfectants, Chlorhexidine, Sodium hypochlorite, Propolis, Ozone, Er,Cr:YSGG laser, bond strength

How to cite this article: Arslan S, Yazici AR, Gorucu J, Ertan A, Pala K, Üstün Y, Antonson SA, Antonson DE. Effects of Different Cavity Disinfectants on Shear Bond Strength of a Siloranebased Resin Composite. J Contemp Dent Pract 2011;12(4): 279-286.

Source of support: None

Conflict of interest: None declared

\section{INTRODUCTION}

Conventional removal of carious tissue and cavity preparation procedures do not guarantee the complete elimination of oral cariogenic bacteria that might be entrapped within the dentin tubules or the smear layer, which may induce secondary caries or pulpal inflamation. ${ }^{1}$ For these reasons, elimination of the bacteria from the cavity surfaces is of major importance. Disinfectant solutions are in general use to reduce or eliminate bacteria from cavity preparations. Some antibacterial solutions have been tested as cavity disinfectants are chlorhexidine digluconate (CHX), sodium hypochlorite $(\mathrm{NaOCl})$, and hydrogen peroxide $\left(\mathrm{H}_{2} \mathrm{O}_{2}\right)^{2}$

Chlorhexidine has been widely used as an antimicrobial agent as well as for disinfection before the placement of restorations. ${ }^{3}$ CHX is a bis-bis-guanide that acts by adsorbing onto the cell wall of microorganisms resulting in leakage of intracellular components. ${ }^{4}$ CHX has a broadspectrum antimicrobial activity, ${ }^{5}$ targeting both grampositive and gram-negative microbes and is biocompatible. ${ }^{6}$ Chlorhexidine is the most potent antimicrobial agent to combat Streptococcus mutans. It has been found to be effective in reducing levels of $S$. mutans found in occlusal fissures and on exposed root surface. ${ }^{7}$ Its efficacy in caries prevention has been shown in many clinical trials. ${ }^{8,9}$

The most commonly used antimicrobial agent up to now has been $\mathrm{NaOCl}$. Depending on the testing methodology and the adhesive system composition, the application of sodium hypochlorite may increase, decrease, or have no effect on bond strengths. ${ }^{10,11}$ In a study conducted by Taniguchi et al, ${ }^{12}$ it was reported that $\mathrm{NaOCl}$ pretreatment for 30s significantly reduced the bond strengths of self-etch adhesive systems to sound dentin, while there were no significant differences in dentin bond strength values between normal dentin and $\mathrm{NaOCl}-15 \mathrm{~s}$ treated groups.

Propolis is a resinous hive substance by honeybees from products collected from plants. It is known to possess valuable antimicrobial, antiviral, fungicidal, local anesthetic, 
antiulser, immunostimulating, hypotensive and cytostatic properties. ${ }^{13}$ Propolis has been used as a remedy for treatment of many diseases in folk medicine since ancient times. A number of studies have been conducted, mainly on animals and to a lesser extent on humans, to investigate propolis in different dental fields. ${ }^{14-16}$ Ethanol extract of propolis produces favorable properties for endodontic use, such as promoting bone regeneration and inducing hard tissue bridge formation in pulpotomies or pulp capping. ${ }^{13,17}$

Gasiform ozone has been introduced in dental practice due to its antimicrobial potential against common oral pathogens. Clinical studies have assessed the effect of ozone for the treatment of oclusal ${ }^{18}$ and root caries ${ }^{19}$ and, more recently, the application of ozone on dental hard tissue prior to adhesive restorations. ${ }^{20,21}$

Another alternative treatment protocol for disinfection the cavities is the use of lasers. The Er,Cr:YSGG laser uses hydrokinetic energy. As a result of this hydrokinetic energy, the Er,Cr:YSGG laser may have ability to disinfection. ${ }^{22}$ Er,Cr:YSGG laser irradiation is able to remove the debris and smear layer efficiently. ${ }^{23}$ Removal of the smear layer serves to eliminate the microorganisms and thus prevent residual caries. Therefore, some researchers believe that the laser may be able to provide restorations with greater bond strength and greater longevity than those obtained by the conventional method. ${ }^{24,25}$

Two major properties of dental composites that remain to be improved are polymerization shrinkage and related polymerization stress. Naturally, the best way to avoid shrinkage stress is to use nonshrinking resins. Recently, a low-shrinking composite, Filtek Silorane was introduced. Siloranes replace the methacrylates in the resin matrix of dental composites. The ring-opening chemistry of the resin reduces shrinkage of the composite below 1\%. Filtek Silorane comes with a two-step self-etch adhesive, commercialized as 'Silorane System Adhesive (SSA) that is specific to this particular chemistry. ${ }^{26}$

A potential problem in the use of a disinfectant before dentin adhesives is the possibility of an adverse interaction on the bond strength of the resin composites. The objective of this study was to compare the effects of different disinfection agents; $\mathrm{CHX}, \mathrm{NaOCl}$, propolis, ozone and Er,Cr:YSGG laser on shear bond strength of a silorane-based resin composite. The null hypothesis was different disinfectant agents do not affect the shear bond of a siloranebased resin composite to dentin.

\section{MATERIALS AND METHODS}

Thirty-six caries-free human third mandibular molars were stored in $0.5 \%$ chloramin solution at $4^{\circ} \mathrm{C}$ and used within one month after extraction. The teeth were sectioned in mesio-distal direction with a low-speed diamond disk (Buehler; Lake Bluff, IL, USA) under water coolant. The sectioned teeth were embedded in autopolymerizing acrylic resin and a flat dentin surface was exposed (Fig. 1). The exposed dentin surfaces were further flattened on wet using a 600 -grit Si-C paper for 60 seconds to standardize the smear layer. The teeth were then rinsed with distilled water to remove any debris and were randomly divided into 6 groups of 12 teeth each.

Group I: A 2\% chlorhexidine gluconate (CHX, Drogsan, Ankara, Turkey) solution absorbed cotton pellet was applied to dentin for 20s. ${ }^{2}$ The dentin surfaces of the teeth were then dried with air for 10s (Fig. 2).

Group II: The surfaces of specimens were treated by rubbing a $2.5 \%$ sodium hypochlorite $(\mathrm{NaOCl})$ solution absorbed cotton pellet for 20s. ${ }^{2}$ The dentin surfaces of the teeth were then rinsed and dried with air for 10s (Fig. 3).

Group III: The surfaces of specimens were treated by rubbing a one drop 30\% propolis absorbed cotton pellet for 20 s. $^{2}$ The dentin surfaces of the teeth were then dried with air for 10s. The propolis sample was collected from Kayseri

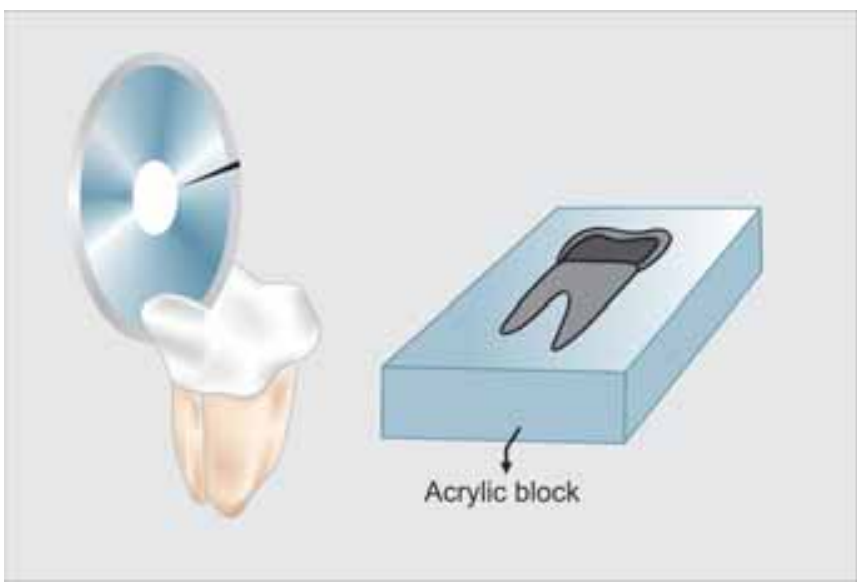

Fig. 1: Specimen preparation

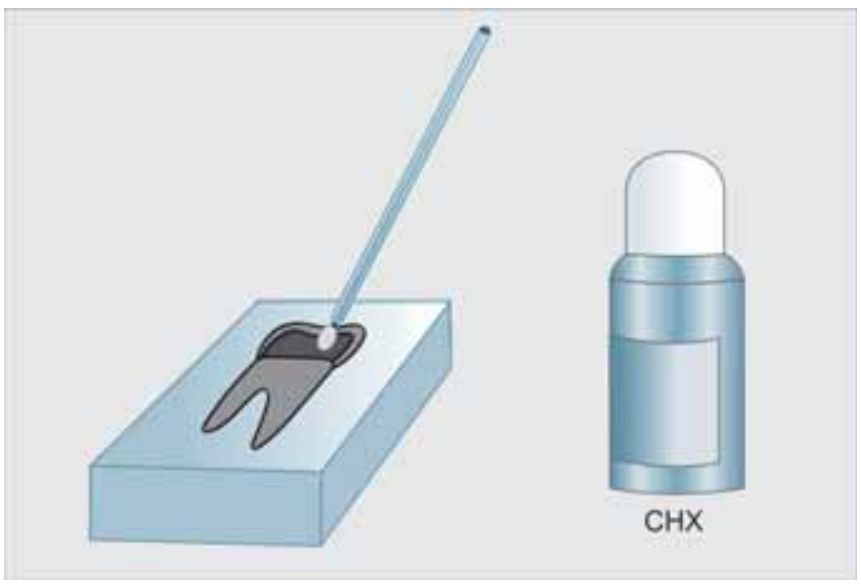

Fig. 2: Chlorhexidine gluconate (CHX) application 
(Central Anatolia), in Turkey. The hand-collected propolis sample was kept desiccated in the dark until it was processed. Subsequently, $30 \mathrm{~g}$ crude propolis was dissolved in $70 \%$ ethanol by shaking for 3 days. The aqueous-ethanol extract was filtered through a Whatman 1 paper and evaporated at $50^{\circ} \mathrm{C}$. The resin obtained was dissolved in $70 \%$ ethanol to $30 \%$ ethanol extract of propolis (EEP) (Fig. 4).

Group IV: Ozone (Ozonytronx, Biozonmylius, GmbH Mymed, Germany) was used to generate ozone gas. Ozone was applied to the dentin surface with PA tip, adjusting device to the third level for 30s (Fig. 5).

Group V: The dentin surfaces were irradiated with a Er,Cr:YSGG laser (Waterlase MD, Biolase, San Clemente, California, CA, USA) emitting photons at a wavelength of $2.780 \mathrm{~nm}$ and a pulse duration of 140 microseconds. The laser energy was delivered through a sapphire tip, $600 \mu \mathrm{m}$ in diameter and $6 \mathrm{~mm}$ long, positioned perpendicular to the dentin surface. A power of $0.75 \mathrm{~W}$ (15\% air, 15\% water) with $20 \mathrm{~Hz}$ was used in focus mode at a 1-2 mm focal distance. The laser was applied to dentin surfaces 5 times for 10s application with 5s intervals (Fig. 6).

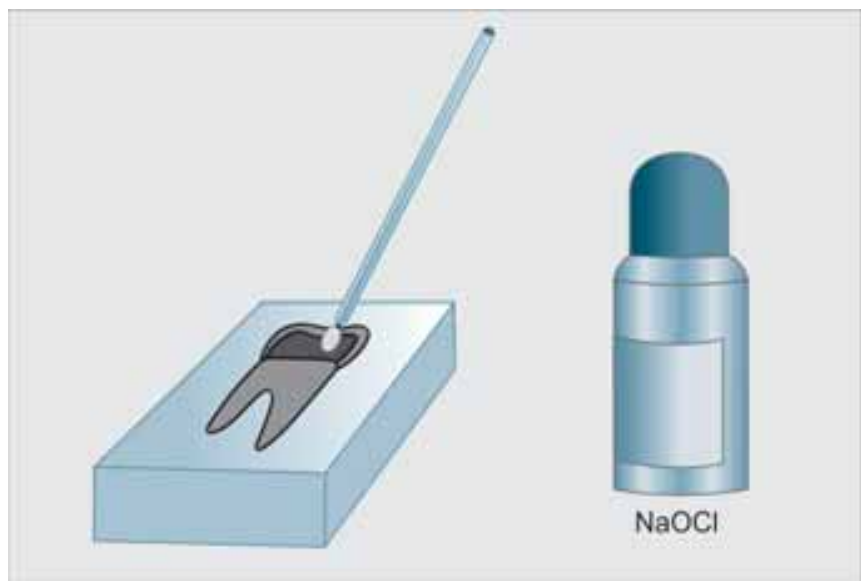

Fig. 3: Sodium hypochlorite (NaOCl) application

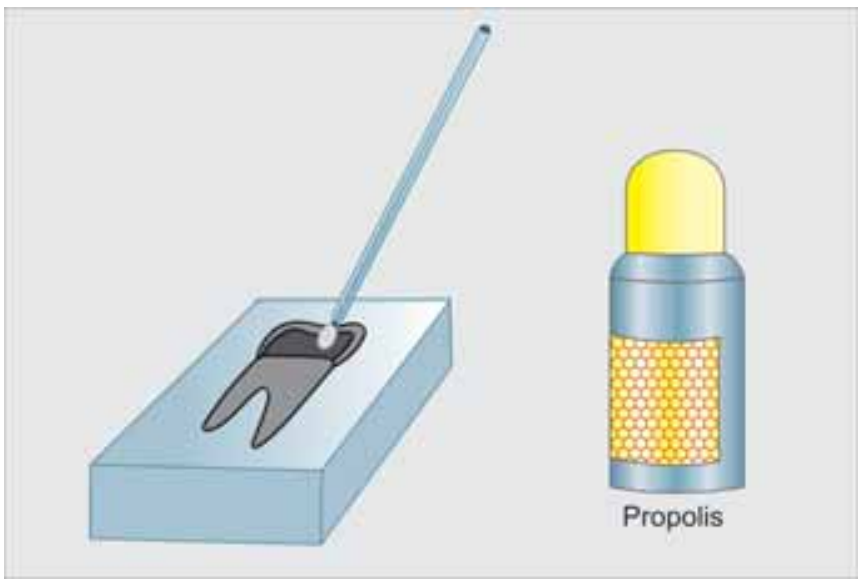

Fig. 4: Propolis application

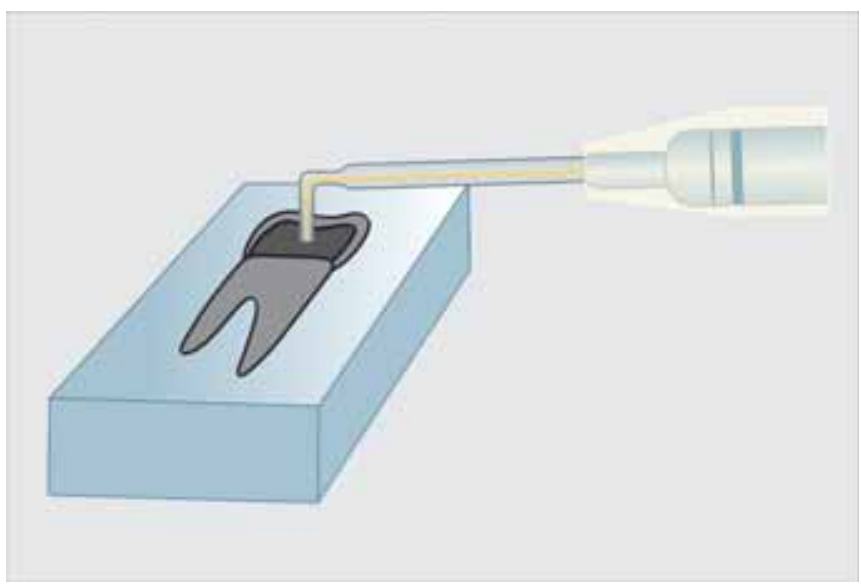

Fig. 5: Ozone application

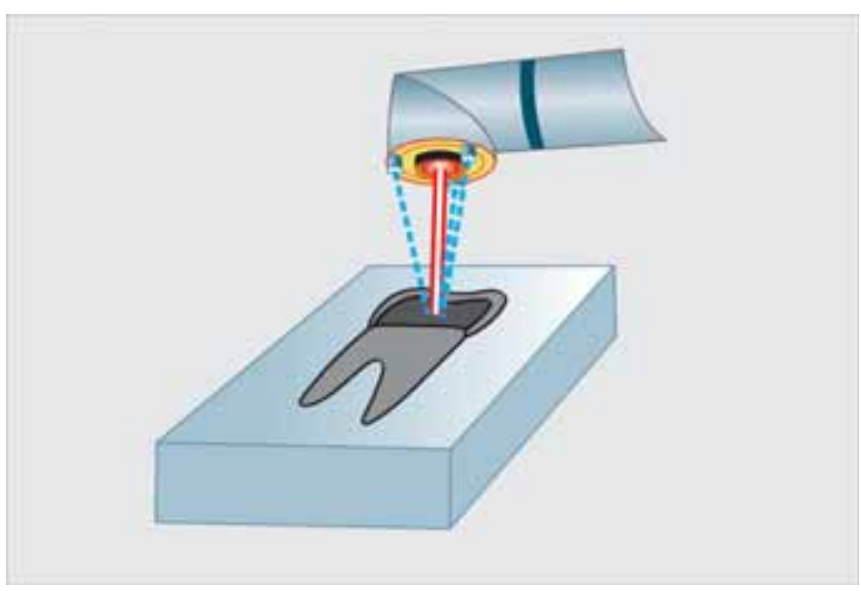

Fig. 6: Er,Cr:YSGG laser application

Group VI: The specimens were not treated with any cavity disinfectant and served as control (Fig. 7).

After treatment of the dentin surfaces, Silorane SelfEtch Primer (3M ESPE, St Paul, MN, USA) was applied and rubbed for $15 \mathrm{~s}$. The dentin surface was dried with air and then light cured for 10s using a quartz-tungsten halogen light (Hilux, Benlioglu, Ankara, Turkey) set at $550 \mathrm{~mW} / \mathrm{cm}^{2}$. Silorane bond was applied to the dentin surface and light cured for 10s using the same light-curing unit (Fig. 8). Transparent gelatin capsules (2.5 mm diameter, $2 \mathrm{~mm}$ high) were used to form and hold the restorative resin onto the dentin surface. A silorane-based resin composite (Filtek Silorane, 3M ESPE, St Paul, MN, USA) was condensed into the capsule and cured for 40s (Table 1) (Fig. 9). Following storage in distilled water at $37^{\circ} \mathrm{C}$ for $24 \mathrm{~h}$, the specimens were tested in shear mode using a knife-edge testing apparatus in a universal testing machine (Lloyd, Hampshire, UK) at a crosshead speed of $1.0 \mathrm{~mm} /$ minute (Fig. 10). The shear strength bond values in MPa were calculated from the peak value load at failure divided by the specimen surface area.

One-way ANOVA was used for multiple comparisons of the bond strengths for the different groups. 


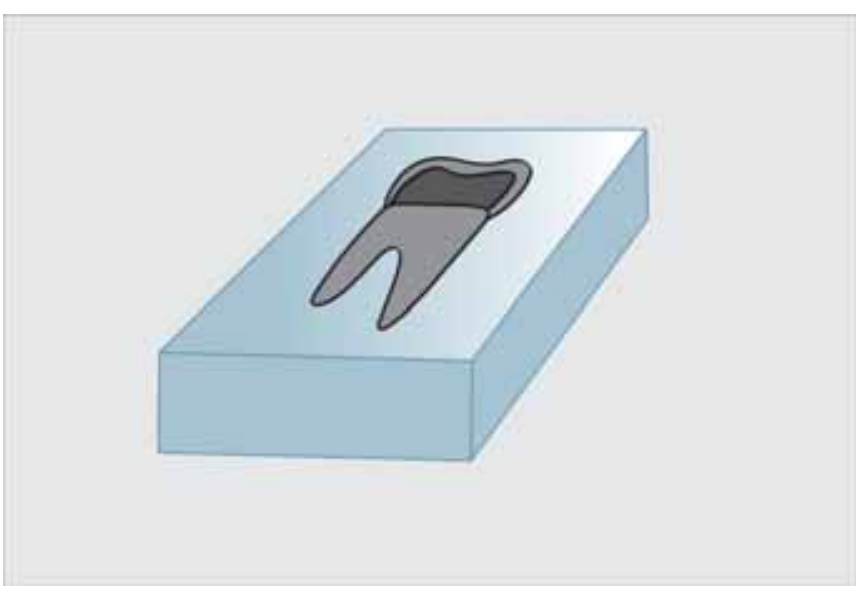

Fig. 7: Control (no treatment)

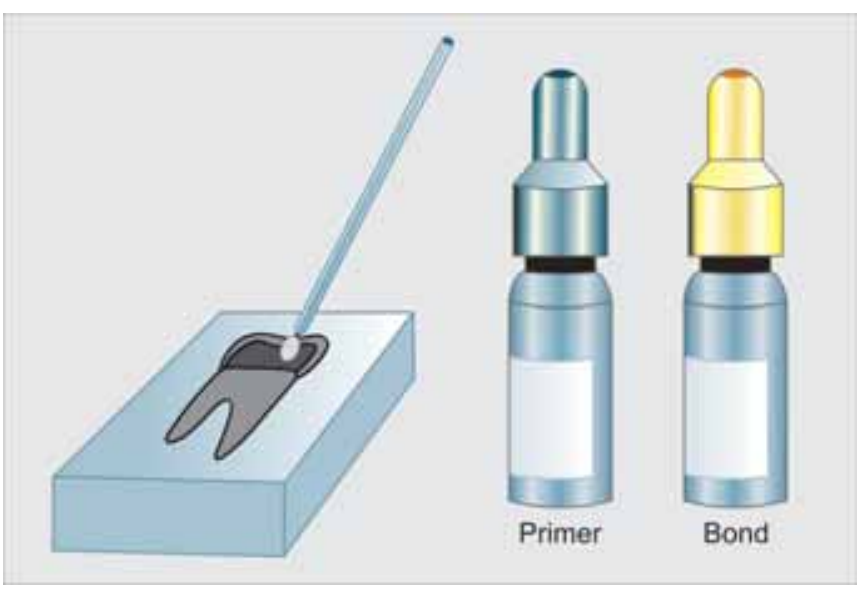

Fig. 8: Adhesive system application

\section{RESULTS}

The mean shear bond strengths and standard deviations of the tested groups are shown in Table 2. One-way ANOVA revealed that the bond strength values were not statistically significant from each other $(\mathrm{p}=0.074)$.

\section{DISCUSSION}

The use of disinfection agents may reduce or eliminate bacteria in cavity preparations and might increase the

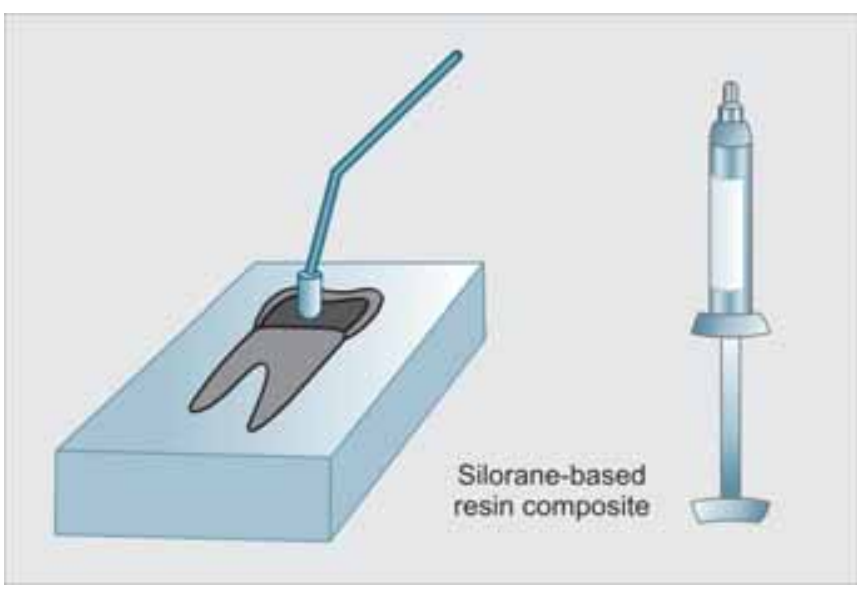

Fig. 9: Resin composite application

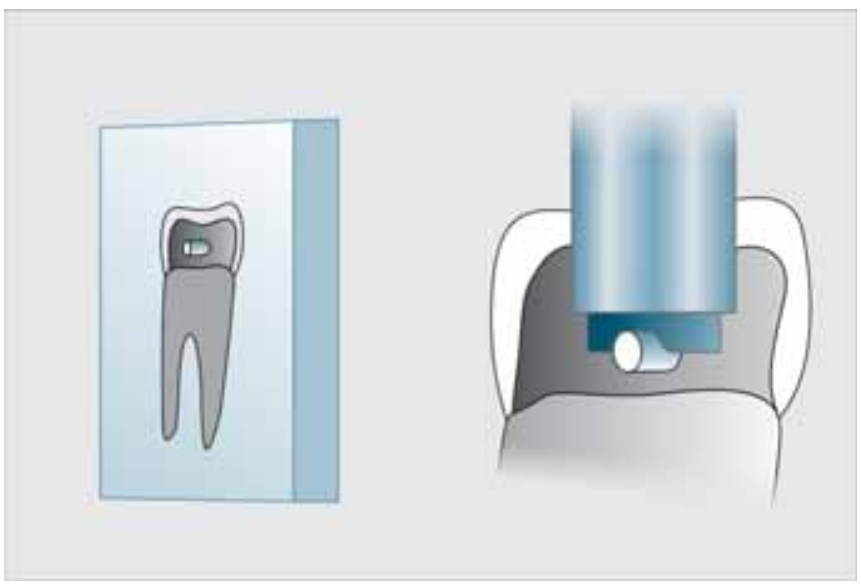

Fig. 10: Shear bond strength test

success and longevity of restorations. On the other hand these agents might affect the bonding ability of resin materials to tooth substrate. Therefore the aim of this study was to compare different disinfection agents' effect on resin bond strength. In the present study, it was found that the cavity disinfectants $\mathrm{CHX}, \mathrm{NaOCl}$, propolis, ozone and Er:Cr:YSGG laser had no adverse effect on the shear bond strength of Filtek Silorane used with a self-etching adhesive system. Thus, the null hypothesis of the current study was accepted.

\section{Table 1. Materials used in this study}

\begin{tabular}{|c|c|}
\hline Materials & Composition \\
\hline $\begin{array}{l}\text { Filtek Silorane } \\
\text { 3M ESPE, St. Paul, MN, USA } \\
\text { Batch\# N1 } 22786\end{array}$ & $\begin{array}{l}\text { Bis-3,4-Epoxycyclohexylethylphenylmethylsilane,3,4-Epoxycyclohexylcyclopolymethylsiloxane, } \\
\text { Silanized, Quartz, Yttrium fluoride }\end{array}$ \\
\hline $\begin{array}{l}\text { Filtek Silorane Primer } \\
\text { 3M ESPE, St. Paul, MN, USA } \\
\text { Batch\# 8BF }\end{array}$ & $\begin{array}{l}\text { Phosphorylated methacrylates, Vitrebond copolymer, Bis-GMA, HEMA, Water, Ethanol, } \\
\text { Silorane-treated silica filler }\end{array}$ \\
\hline $\begin{array}{l}\text { Filtek Silorane Adhesive } \\
\text { 3M ESPE, St. Paul, MN, USA } \\
\text { Batch\# 8BB }\end{array}$ & $\begin{array}{l}\text { Hydrophobic dimethacrylate, Phosphorylated methacrylates, TEGDMA, Silorane-treated } \\
\text { silica filler }\end{array}$ \\
\hline
\end{tabular}

Bis-GMA: bis-phenol A diglycidylmethacrylate; HEMA: 2-hydroxyethyl methacrylate; TEGDMA: Triethylene glycol dimethacrylate 


\begin{tabular}{|c|c|c|}
\hline Groups & $\begin{array}{l}\text { Shear bond } \\
\text { strength }\end{array}$ & $\begin{array}{c}\text { Standard } \\
\text { deviation }(S D)\end{array}$ \\
\hline Group I (CHX) & 13.76 & 1.31 \\
\hline Group II (NaOCl) & 13.17 & 1.35 \\
\hline Group III (Propolis) & 14.51 & 1.63 \\
\hline Group IV (Ozone) & 14.07 & 1.35 \\
\hline Group V (Laser) & 13.32 & 1.48 \\
\hline Group VI (Control) & 14.55 & 1.67 \\
\hline
\end{tabular}

CHX has been proven to be the most effective and safe disinfectant agent for many years. ${ }^{4}$ As it has a rewetting capacity and a strong affinity to tooth structure, it might have been expected that CHX would improve dentin bond strengths. The results of the present study, which shows no adverse effect on bond strength, are contrary to previous in vitro studies. ${ }^{2,27}$ According to a study of Ercan et $\mathrm{al}^{2}$ the pretreatment of dentin surfaces with $\mathrm{NaOCl}, \mathrm{H}_{2} \mathrm{O}_{2}$ or $\mathrm{CHX}$ solutions had a negative effect on the shear bond strength of self-etch adhesive systems. They suggested preferring an etch-and-rinse adhesive when $\mathrm{NaOCl}, \mathrm{H}_{2} \mathrm{O}_{2}$ or chlorhexidine solutions are used as a cavity disinfectant. In the other study, while $0.12 \%$ and $2 \%$ CHX did not show any influence on the bond strength of etch-and-rinse adhesive systems, the application of $2 \%$ CHX was found to be deleterious to self-etch adhesive systems. ${ }^{27}$ They recommended avoiding using CHX-based cavity disinfectants in concentrations higher than $0.12 \%$ prior to the self-etch adhesive system's application. Celik et al found that CHX's effect on bond strength might differ according to the type of the adhesive system used. ${ }^{28}$ Ricci et $\mathrm{al}^{29}$ evaluated the influence of CHX application on the immediate microtensile bond strength of three different twostep etch-and-rinse adhesive systems to the dentin of primary and permanent teeth. However, they applied CHX after acid etching. While CHX application increased the bond of Prime \& Bond NT and Single Bond to the acid-etched dentin, no positive or negative effect was observed for Excite DSC. They concluded that the treatment of phosphoric acid-etched dentin with a $2 \%$ CHX solution did not affect negatively the bond strength of etch-and-rinse adhesive systems. Similar to our findings, Soares et $\mathrm{al}^{30}$ also reported that the use of CHX before, after or associated with acid-etching did not significantly affect the bond strength values to dentin. Recently, the use of CHX in an aqueous solution or associated with the acid conditioner was found to be effective to reduce the degradation of dentin bonds over a 2-year period. ${ }^{31}$ However, in some studies, the CHX solution exerted an adverse effect on shear bond strength when used with a self-etch adhesive system. ${ }^{2,27}$

Sodium hypochlorite has been used as one of the most common cavity disinfectants in clinical practice. Although it has been proposed that the dentin substrate after deproteinization exhibits a remarkably porous structure with multiple irregularities, controversial still results about its' effect on bond strength., ${ }^{2,12}$ Most studies report the decreased bond strength values after $\mathrm{NaOCl}$ treatment. ${ }^{2,32,33}$ It has been claimed that remnants of superoxide radicals generated by $\mathrm{NaOCl}$ within the dentin surface inhibit polymerization of resin monomers. However in the present study, $\mathrm{NaOCl}$ had no adverse effect on bond strength when the self-etching system was used. This might be related with the adhesive systems' composition. On the other hand, rinsing the treated surfaces with water could remove the oxidized products from the dentin surface. In another study it was reported that the effects of $\mathrm{NaOCl}$ pretreatment on bonding of both self-etch adhesives were dependent upon type of dentin (normal and caries-affected dentin) and the treatment time. ${ }^{12}$

Propolis's antimicrobial efficacy has been shown in several studies. ${ }^{14-16}$ Many recent studies showed that a subinhibitory concentration of EEP was used to record its action on some important virulence factors like lipase and coagulase enzymes, and biofilm formation in Staphylococcus aureus ${ }^{33}$ and mutant streptococci. ${ }^{34,35}$ Koo et $\mathrm{al},{ }^{36}$ stated that mouthrinses containing propolis showed significant reduction of dental plaque compared to the placebo, and also significant inhibition of insoluble polysaccharide formation. In our study, propolis had no adverse effect on bond strength when used as a cavity disinfectant. To the extent of author's knowledge, no study has been conducted in the literature that evaluated the propolis's effect on bond strength.

Ozone is a promising alternative caries-management strategy, and has opened a wide range of potential treatment protocols. One of these therapeutic options could be the effective disinfection of cavities after conventional removal of caries, which may reduce the risk of residual caries formation and inflammation of the pulp due to remaining bacteria in dentinal tubules. ${ }^{37}$ This strong oxidant has been shown to effectively kill up to $99.9 \%$ of bacteria present after an application period of only 20s. ${ }^{38}$ The application of ozone with a concentration of 2,100 ppm for 80s on an in vitro infected dentinal cavity model has been reported to be successful in reducing the number of microorganism, thus confirming the potential of this treatment to disinfect carious cavities. ${ }^{39}$ Ozone is also able to break up acidic products of cariogenic bacteria. The results of our study indicate that using ozone prior to the application of Filtek Silorane did not affect the bonding ability. Gürgan et al, ${ }^{40}$ evaluated the effect of ozone and Nd:YAG laser pretreatment on bond strength of self-etch adhesives to coronal and root dentin. Similar to our study, they also found pretreatments with ozone did not impair the bond strength 
of self-etch adhesives. In an in vitro study, the influence of direct high-dose gaseous ozone on dentin and enamel bond strength was evaluated. Despite possible retention of surface and subsurface oxide-related substances during high-dose ozone application, shear bond strength was not impaired. ${ }^{41}$ It was also found that the use of ozone gas to disinfect the cavity before placing a restoration had no influence on immediate enamel and dentin bond strength. ${ }^{42}$

The disinfecting ability of different types of lasers has been studied from several aspects. In a recent study, the effect of two different cavity disinfection procedures; CHXbased cavity disinfectant and Er,Cr:YSGG laser irradiation was evaluated on the bond strength of an etch-and-rinse and self-etch adhesive. ${ }^{27}$ While CHX and laser irradiation produced significantly higher bond strength values compared to the untreated group for etch-and-rinse adhesive, laser irradiation improved the bond strength for the selfetch adhesive. They concluded that as a cavity-disinfecting procedure, laser irradiation enhanced the bond strength of etch and rinse and self-etch adhesive systems. Siso et $\mathrm{al}^{43}$ evaluated the microleakage of class $\mathrm{V}$ composite restorations after antimicrobial pretreatments; KTP laser irradiation, 2\% $\mathrm{CHX}$ and Clearfil Protect Bond. While there were no significant differences between the groups on dentin margins, KTP laser irradiation exhibited the lowest microleakage scores on enamel margins. However, contradictory results have also been reported in the literature regarding the bonding effectiveness of adhesive systems to laser-irradiated dentin. While some studies demonstrated a decrease in bond strength values after laser irradiation, ${ }^{44,45}$ some found no difference. ${ }^{46,47}$ In an in vitro study, the dentin bond strength to resin composite following erbium:yttriumaluminum-garnet (Er:YAG) laser preparation using different adhesive systems was evaluated. The results suggested that dentin surfaces prepared with an Er:YAG laser may provide comparable composite resin bond strengths depending on the adhesives used. ${ }^{48}$ The diversity of these results might be related with the laser output, and also with the composition of adhesive systems used. It has been claimed that the dentine surfaces irradiated by the Er,Cr:YSGG laser showed a scaly and rugged appearance and open dentinal tubules without smear layer production. ${ }^{49}$ On the other hand, lased dentin revealed an imbricate patterned substrate and the presence of microcracks at the dentin surface. ${ }^{44}$ Our study showed that the use of a laser to disinfect the cavity before placing a restoration did not influence the bond strength.

According to the data we obtained, the bond strength values to dentin were very low. The self-etching primer of the Silorane System Adhesive has a pH of 2.7 and thus can be classified as 'ultra-mild'. This might be related with the $\mathrm{pH}$ of this system. As the use of Filtek Silorane resin composite is increasing day by day because of its low shrinkage properties, these results should be supported with future clinical studies to determine whether the same results would be found in vivo as were found in vitro in the current study.

\section{CONCLUSION}

According to the limitations of the current study, it can be concluded that cavity disinfection with $\mathrm{CHX}, \mathrm{NaOCl}$, propolis, ozone, and laser did not significantly affect the bond strength of Filtek Silorane used with its' respective self-etch adhesive system.

\section{CLINICAL SIGNIFICANCE}

Cavity disinfectant applications did not affect the dentin bond strength of a silorane-based resin composite.

\section{REFERENCES}

1. Meiers JC, Kresin JC. Cavity disinfectants and dentin bonding Oper Dent Jul-Aug 1996;21(4):153-59.

2. Ercan E, Erdemir A, Zorba YO, Eldeniz AU, Dalli M, Ýnce B, et al. Effect of different cavity disinfectants on shear bond strength of composite resin to dentin J Adhes Dent Oct 2009; 11(5):343-46.

3. Carrilho MR, Carvalho RM, de Goes MF, di Hipólito V, Geraldeli S, Tay FR, et al. Chlorhexidine preserves dentin bond in vitro. J Dent Res Jan 2007;86(1):90-94.

4. Matthijs S, Adriaens PA. Chlorhexidine varnishes: A review. J Clin Periodontol Jan 2002;29(1):1-8.

5. Delany GM, Patterson SS, Miller CH, Newton CW. The effect of chlorhexidine gluconate irrigation on the root canal flora of freshly extracted necrotic teeth. Oral Surg Oral Med Oral Pathol May 1982;53(5):518-23.

6. Yesilsoy C, Whitaker E, Cleveland D, Phillips E, Trope M. Antimicrobial and toxic effects of established and potential root canal irrigants. J Endod Oct 1995;21(10):513-15.

7. Gürgan S, Bolay S, Kiremitci A. Effect of disinfectant application methods on the bond strength of composite to dentin. J Oral Rehabil Oct 1999;26(10):836-40.

8. Baca P, Junco P, Bravo M, Baca AP, Muñoz MJ. Caries incidence in permanent first molars after discontinuation of a school-based chlorhexidine-thymol varnish program Com Dent Oral Epidemiol Jun 2003;31(3):179-83.

9. Baca P, Clavero J, Baca AP, González-Rodríguez MP, Bravo M, Valderrama MJ. Effect of chlorhexidine-thymol varnish on root caries in a geriatric population: a randomized double-blind clinical trial. J Dent Sep 2009;37(9):679-85.

10. Perdigao J, Lopes M, Geraldelli S, Lopes GC, Garcia-Godoy F. Effect of sodium hypochlorite gel on dentin bonding. Dent Mater Sep 2000;16(5):311-23.

11. Arias VG, Bedran-de-Castro AK, Pimenta LA. Effect of sodium hypochlorite gel and sodium hypochlorite solution on dentin bond strength. J Biomed Mater Res Part B: Appl Biomater Feb 2005;72(2):339-44. 
12. Taniguchi G, Nakajima M, Hosaka K, Iwamoto N, Ikeda M, Foxton RM, et al. Improving the effect of $\mathrm{NaOCl}$ pretreatment on bonding to caries-affected dentin using self-etch adhesives. J Dent Oct 2009;37(10):769-75.

13. Gulinelli JL, Panzarini SR, Fattah CM, Sonoda CK, Negri MR, Saito CM. Effect of root surface treatment with propolis and fluoride in delayed tooth replantation in rats. Dent Traumatol Dec 2008;24(6):651-57.

14. Ferreira FB, Torres SA, Rosa OP, Ferreira CM, Garcia RB, Marcucci MC, et al. Antimicrobial effect of propolis and other substances against selected endodontic pathogens Oral Surg Oral Med Oral Pathol Nov 2007;104(5):709-16.

15. Awawdeh L, Al-Beitawi M, Hammad M. Effectiveness of propolis and calcium hydroxide as a short-term antracanal medicament against Enterococcus faecalis: A laboratory study Aust Endod J Aug 2009;35(2):52-58.

16. Kandaswamy D, Venkateshbabu N, Gogulnath D, Kindo AJ. Dentinal tubule disinfection with $2 \%$ chlorhexidine gel, propolis, morinda citrifolia juice, $2 \%$ povidone iodine, and calcium hydroxide. Int Endod J May 2010;43(5):419-23.

17. Parolia A, Kundabala M, Rao NN, Acharya SR, Agrawal P, Mohan P, et al. A comparative histological analysis of human pulp following direct pulp capping with propolis, mineral trioxide aggregate and Dycal. Aust Dent J Mar 2010;55(1):59-64.

18. Huth KC, Paschos E, Brand K, Hickel R. Effect of ozone on non-cavitated fissure carious lesions in permanent molars. A controlled prospective clinical study. Am J Dent Aug 2005; 18(4):223-28.

19. Baysan A, Lynch E. Clinical reversal of root caries using ozone: 6-month results. Am J Dent Aug 2007;20(4):203-18.

20. Magni E, Ferrari M, Hickel R, Huth KC, Ilie N. Effect of ozone gas application on the mechanical properties of dental adhesives bonded to dentin. Dent Mater Oct 2008;24(10):1428-34.

21. Cehreli SB, Guzey A, Arhun N, Cetinsahin A, Unver B. The effects of prophylactic ozone pretreatment of enamel on shear bond strength of orthodontic brackets bonded with total or selfetch adhesive systems. Eur J Dent Oct 2010;4(4):367-73.

22. Eldeniz AU, Ozer F, Hadimli HH, Erganis O. Bactericidal efficacy of Er,Cr:YSGG laser irradiation against faecalis compared with $\mathrm{NaOCl}$ irrigation an ex vivo pilot study Int Endod J Feb 2007;40(2):112-19.

23. Türkün M, Türkün SL, Çelik EU, Ateş M. Bactericidal effect of Er,Cr.YSGG laser on Streptococcus mutans. Dent Mater Mar 2006;25(1):81-86.

24. Geraldo-Martins VR, Robles FR, Matos AB. Chlorhexidine’s effect on sealing ability of composite restorations following Er:YAG laser cavity preparation. J Contemp Dent Prac Jul 2007; 8(5):26-33.

25. Marotti J, Geroldo-Martins VR, Bello-Silva MS, de Paula Eduardo C, Apel C, Gutknecht N. Influence of etching with erbium, chromium:yttrium-scandium-garnet laser on microleakage of class V restoration. Lasers Med Sci May 2010; 25(3):325-29.

26. Weinmann W, Thalacker C, Guggenberger R. Siloranes in dental composites. Dent Mater Jan 2005;21(1):68-74.

27. Campos EA, Correr GM, Leonardi DP, Pizzatto E, Morais EC. Influence of chlorhexidine concentration on microtensile bond strength of contemporary adhesive systems. Braz Oral Res JulSep 2009;23(3):340-45.

28. Celik C, Ozel Y, Bağiş B, Erkut S. Effect of laser irradiation and cavity disinfectant application on the microtensile bond strength of different adhesive systems. Photomed Laser Surg Apr 2010;28(2):267-72.
29. Ricci HA, Sanabe ME, Costa CA, Hebling J. Effect of chlorhexidine on bond strength of two-step etch-and-rinse adhesive systems to dentin of primary and permanent teeth. Am J Dent Jun 2010:23(3):128-32.

30. Soares CJ, Pereira CA, Pereira JC, Santana FR, do Prado CJ. Effect of chlorhexidine application on microtensile bond strength to dentin. Oper Dent Mar-Apr 2008;33(2):183-88.

31. Stanislawczuk R, Reis A, Loguercio AD. A 2-year in vitro evaluation of a chlorhexidine-containing acid on the durability of resin-dentin interfaces. J Dent Jan 2011;39(1):40-47.

32. Öztürk B, Özer F. Effect of $\mathrm{NaOCl}$ on bond strengths of bonding agents to pulp chamber lateral walls. J Endod May 2004;30(5): 362-65.

33. Vongphan N, Senawongse P, Somsiri W, Harnirattisai C. Effects of sodium ascorbate on microtensile bond strength of totaletching adhesive system to $\mathrm{NaOCl}$ treated dentine. J Dent Sep 2005;33(8):689-95.

34. Scazzocchio F, D’Auria FD, Alessandrini D, Pantanella F. Multifactorial aspects of antimicrobial activity of propolis. Microbiol Res Jan 2006;161(4):327-33.

35. Duarte S, Rosalen PL, Hayacibara MF, Cury JA, Bowen WH, Marquis RE. The influence of a novel propolis on mutans streptococci biofilms and caries development in rats. Arch Oral Biol Jan 2006;51(1):15-22.

36. Koo H, Cury JA, Rosalen PL, Ambrosano GM, Ikegaki M, Park YK. Effect of a mouthrinse containing selected propolis on 3day dental plaque accumulation and polysaccharide formation. Caries Res Nov-Dec 2002;36(6):445-48.

37. Martin FE, Nadkarni MA, Jacques NA, Hunter N. Quantitative microbiological study of human carious dentine by culture and real-time PCR: Association of anaerobes with histopathological changes in chronic pulpitis. J Clin Microbiol May 2002;40(5): 1698-704.

38. Baysan A, Whiley RA, Lynch E. Antimicrobial effect of a novel ozone-generating device on microorganisms associated with primary root carious lesions in vitro. Caries Res Nov-Dec 2000;34(6):498-501.

39. Polydorou O, Pelz K, Hahn P. Antibacterial effect of an ozone device and its comparison with two dentin-bonding systems. Eur J Oral Sci Aug 2006;114(4):349-53.

40. Gürgan S, Firat E, Baysan E, Gutknecht N, Imazato S. Effect of ozone and ND:YAG laser pretreatment on bond strength of selfetch adhesives to coronal and root dentin. Photomed Laser Surg Oct 2010;28 (Supp 2):3-8.

41. Schmidlin PR, Zimmermann J, Bindl A. Effect of ozone on enamel and dentin bond strength. J Adhes Dent Spring 2005; $7(1): 29-32$.

42. Cadenaro M, Delise C, Antoniolli F, Navarra OC, Lenardo R, Breschi L. Enamel and dentin bond strength following gaseous ozone application. J Adhes Dent Aug 2009;11(4):287-92.

43. Siso HS, Kustarci A, Göktolga EG. Microleakage in resin composite restorations after antimicrobial pre-treatments: Effect of KTP laser, chlorhexidine gluconate and Clearfil Protect Bond. Oper Dent May-Jun 2009;34(3):321-27.

44. Cardoso MV, Coutinho E, Ermis RB, Poitevin A, Van Landuyt K, De Munck J, et al. Influence of Er,Cr:YSGG laser treatment on the microtensile bond strength of adhesives to dentin. J Adhes Dent Feb 2008;10(1):25-33.

45. Yazici AR, Karaman E, Ertan A, Ozgunaltay G, Dayangac B. Effect of different pretreatment methods on dentin bond strength on one step self-etch adhesive. J Contemp Dent Prac Jan 2009; 10(1):41-48. 
46. Ergücü Z, Celik EU, Unlü N, Türkün M, Ozer F. Effect of Er,Cr:YSGG laser on the microtensile bond strength of two different adhesives to the sound and caries-affected dentin. Oper Dent Jul-Aug 2009;34(4):460-66.

47. Kayema A, Kato J, Aizava K, Suemoni T, Nakazawa Y, Ogata T, et al. Tensile bond strength of one-step self-etch adhesives to Er:YAG laser-irradiated and non-irradiated enamel. Dent Mater J May 2008;27(3):386-91.

48. Gürgan S, Kiremitçi A, Cakir FY, Yazici E, Gorucu J, Gutknecht N. Shear bond strength of composite bonded to erbium:yttrium-aluminum-garnet laser-prepared dentin. Lasers Med Sci Jan 2009;24(1):117-22.

49. Chou JC, Chen CC, Ding SJ. Effect of Er,Cr:YSGG laser parameters on shear bond strength and microstructure of dentine. Photomed Laser Surg Jun 2009;27(3):481-86.

\section{ABOUT THE AUTHORS}

\section{Soley Arslan}

Instructor, Department of Restorative Dentistry and Endodontics School of Dentistry, Erciyes University, Kayseri, Turkey

\section{A Ruya Yazici}

Professor, Department of Conservative Dentistry, School of Dentistry Hacettepe University, Ankara, Turkey

\section{Jale Gorucu}

Professor, Department of Conservative Dentistry, School of Dentistry Hacettepe University, Ankara, Turkey

\section{Atilla Ertan}

Associate Professor, Department of Prosthodontics, School of Dentistry, Hacettepe University, Ankara, Turkey

\section{Kanşad Pala}

Instructor, Department of Restorative Dentistry and Endodontics School of Dentistry, Erciyes University, Kayseri, Turkey

\section{Yakup Üstün}

Instructor, Department of Restorative Dentistry and Endodontics School of Dentistry, Erciyes University, Kayseri, Turkey

\section{Sibel A Antonson}

Clinical Associate Professor, Department of Restorative Dentistry University at Buffalo, State University of New York School of Dental Medicine, Buffalo, New York, USA

\section{Donald E Antonson}

Professor, Department of Restorative Dentistry, University at Buffalo State University of New York School of Dental Medicine, Buffalo New York, USA

\section{CORRESPONDING AUTHOR}

A Ruya Yazici, Professor, Department of Conservative Dentistry, School of Dentistry, Hacettepe University, Ankara, Turkey Phone: +90-312-305-22-70, e-mail: ruyay@hacettepe.edu.tr 